\title{
Inspiring Educators and a Pedagogy of Kindness: A Reflective Essay
}

\author{
Elizabeth Gorny-Wegrzyn*, Beth Perry \\ Athabasca University, Athabasca, Alberta, Canada \\ Email: *egornywegrzyn@athabascau.ca
}

How to cite this paper: Gorny-Wegrzyn, E., \& Perry, B. (2021). Inspiring Educators and a Pedagogy of Kindness: A Reflective Essay. Creative Education, 12, 220-230. https://doi.org/10.4236/ce.2021.121017

Received: December 14, 2020

Accepted: January 23, 2021

Published: January 26, 2021

Copyright $\odot 2021$ by author(s) and Scientific Research Publishing Inc. This work is licensed under the Creative Commons Attribution International License (CC BY 4.0).

http://creativecommons.org/licenses/by/4.0/

\begin{abstract}
The purpose of this reflective essay was to explore the literature on educators that employ kindness as an approach to pedagogy in higher education. Through a series of reflections, we then considered how educators using a teaching philosophy guided by a pedagogy of kindness influenced learners' lives, enhanced their social consciousness, and facilitated meaningful learning. To begin, we summarized research reports from peer-reviewed journals and articles from grey literature. Questions that guided the literature search were, how does the use of a teaching philosophy based on a pedagogy of kindness affect the learning environment for students and does it modify their attitudes towards social injustice, does this teaching philosophy improve academic outcomes for learners, and is there a possible link between a pedagogy of kindness and teaching success? In sum, the literature revealed that a teaching philosophy based on a pedagogy of kindness is a common approach used by inspiring educators. Further, this teaching philosophy positively influences students, their learning environments, their educational achievements, and engages them to reflect on issues of social justice. A pedagogy of kindness also results in increased career fulfillment for teachers. Our reflections provide examples of these conclusions.
\end{abstract}

\section{Keywords}

Pedagogy of Kindness, Higher Education, Exemplary Teachers, Teaching Strategies, Reflective Writing

\section{Introduction}

Throughout history, philosophers, academics, and researchers have deliberated 
about education, its purpose, practices, and underlying philosophical ideals (Siegel, 2010). Educational issues considered and debated since ancient times include the educational rights of learners and of society as a whole; the essential and desired curricula taking into account ethical, social, and political considerations; and the attributes and responsibilities of educators including, what teaching philosophies and strategies they should employ (Serbati et al., 2020; Siegel, 2010).

Presently, there still exists a social structure in higher teaching institutions that can be oppressive, paternalistic, and domineering (Breuing, 2011). This construct creates unequal power distribution in the teacher-student dyad. The educator can be the oppressor and the learner the oppressed, in that the teacher has the authority and the power and the student has none (Breuing, 2011; Giroux, 1997; Thomas, 2019; Weiler, 2001). This hierarchal structure of power, where the learner is dependent on the teacher, weakens social consciousness and undermines necessary social change (in terms of equality in race, gender, class, age, religion, and culture) (Breuing, 2011). To counter this unequal distribution of power, theorists expound on pedagogies that can help equalize these differentials, enabling learners to think independently and have a voice of their own.

Some theorists and academics endorse the concepts of critical pedagogy, which aims to support a world that is more socially just (Breuing, 2011; Giroux, 1997). Critical pedagogy is student-centered, politically oriented to social equality and change, includes practical experiences both inside and outside of the classroom adjoined to theory and is empowering and emancipatory for students of diverse backgrounds and life experiences (Breuing, 2011; Giroux, 1997). Other theorists espouse pedagogies based on hope (Hooks, 2003). In her book, Teaching Community: A Pedagogy of Hope, hooks champions a pedagogy where a sense of community, kinship, and unity with others (both in the academy and in the outside world) is maintained and where students and educators can work together as equal partners in a learning environment that can expand minds and enhance social consciousness.

In our current time of struggle with matters of race, gender, and class, we need a pedagogy that can help learners from diverse cultures and backgrounds become empowered, have an active voice in their learning experiences, become more engaged with class activities and issues of social justice, and feel more worthy as students and as human beings. Many theorists believe that a pedagogy of kindness (along with care and compassion) can meet these goals (Clegg \& Rowland, 2010; Groves et al., 2015; Hativa et al., 2001; Loreman, 2011; Serbati et al., 2020; Thomas, 2019). Clegg and Rowland (2010) note that addressing kindness in higher education pedagogy may unsettle the established systems of the institution, those of "neo-liberal assumptions that place value on utility and cost above other human values" (p. 720). Yet, Clegg and Rowland (2010) also assert that kindness used in pedagogy can enhance learning environments and learner outcomes and forge an educator-student bond that commits to social justice. 
In this reflective essay, we expound on the theme of inspiring educators, their teaching philosophies, and their influence on students' lives and success. We examine the literature related to one specific teaching philosophy, a pedagogy of kindness, and look at the outcomes for learners and educators when this philosophy is utilized. Specifically, we explore how outstanding educators who follow a teaching philosophy guided by a pedagogy of kindness influence students' academic and personal lives. We searched and summarized the literature on the attributes of extraordinary educators; we also explored these educators' use of a teaching philosophy that uses kindness (as well as care, compassion, and empathy) in their pedagogy. We asked the questions, how does the use of a teaching philosophy founded on a pedagogy of kindness affect students' learning environments, and does this philosophy help improve academic outcomes and increase social consciousness for learners? Finally, we included a series of personal reflections (from both an educator's and student's point of view). The student reflections focus on experiences with exceptional educators who used kindness in their pedagogy and how these experiences touched and changed the student's life and learning. Reflections from an educator who follows this teaching philosophy provide additional answers to the questions posed.

\section{Defining a Pedagogy of Kindness and the Link to Educator Success}

A pedagogy of kindness is a teaching philosophy that is guided by kindness, compassion, and care (Hativa et al., 2001; Serbati et al., 2020). The use of kindness, which includes care and empathy as a teaching strategy in higher education, can positively influence learning environments and learner outcomes (Clegg \& Rowland, 2010). Educators who can identify with students and form strong teacher-student relationships positively impact learners' feelings of self-worth, and these educators can favorably influence learners' academic achievements (Clegg \& Rowland, 2010). Moreover, kindness as a foundation for an educational relationship can also be significant as a commitment to social justice. Clegg and Rowland (2010) explain, "kindness as a public virtue, built upon a commitment to social justice, embraces critique. In educational research, the term 'critical friend' is used by action researchers to describe the relationship between co-enquirers (be they researchers or students) who share a commitment to social justice. It combines the kindness of friendship with the critique of the educator" (p. 723). The use of kindness as a pedagogical philosophy is a complicated concept that requires an instructor to significantly identify with student concerns and try to see things from their perspective. This deep understanding of each student's individual struggles as they work to grasp new ways of learning is one of the qualities found in inspirational educators (Clegg \& Rowland, 2010).

Other qualities of outstanding educators include being organized, animated, and communicating with clarity and enthusiasm, but just as importantly, extraordinary instructors empathize with students and form educator-learner connections based 
on mutual trust and respect (Hativa et al., 2001; Serbati et al., 2020). The use of kindness as a pedagogical strategy can benefit learner outcomes because students who feel valued become more engaged and feel motivated to try harder at academic endeavors (Clegg \& Rowland, 2010). As well, the use of kindness in higher education pedagogy can nurture learning environments where students feel comfortable in exchanging ideas with each other (and with the teacher) and where learners actively listen and cooperate (Magnet et al., 2014). The exchange of divergent thoughts and the freedom to voice opinions in an academic setting can foster intellectual curiosity and can help change prejudicial attitudes toward social injustices (Breuing, 2011; Magnet et al., 2014).

Current literature reveals that the most significant factor in encouraging student learning and promoting favorable learner outcomes is the development of educator-student relationships based on kindness, respect, and empathy (Khan \& Armstrong, 2019). Successful and effective teaching strategies put the focus on students, improving both their learning environments and their satisfaction with learning experiences (Henard \& Roseveare, 2012). Increasing student satisfaction makes learners more engaged in scholastic endeavors and thus enhances their achievement of learning outcomes (Hativa et al., 2001; Serbati et al., 2020). In the same sense, strong academic connections and using kindness to cultivate those connections can spark students' interest and engage them to participate in discussions that may enlighten their social consciousness (Magnet et al., 2014).

The literature consistently shows that educators who work to create mutually respectful bonds with learners establish rich and satisfying learning environments that lead to positive learner outcomes (Hativa et al., 2001; Serbati et al., 2020). A case study of two cohorts of university students (and their reflections on academic life) by Groves et al. (2015) concluded that the most significant factor positively impacting student engagement, student involvement in studies, and learner success was the educator-student relationship. Further, the students' observations in the Groves et al. study on teacher-student relationships indicated that learners appreciated instructors who were proficient, organized, and animated but placed more value on teachers who were welcoming, accessible, and who had a sincere interest in the students' personal and academic lives (2015). A student's reflections in an online graduate program that follows illustrate the effects of a pedagogy of kindness on learners. Likewise, the educator's reflection that follows demonstrates that a pedagogy of kindness has mutual benefits for learners and educators.

\section{A Student's Experience with a Pedagogy of Kindness}

Returning to university to pursue my Master of Nursing degree was always a dream of mine. I graduated with my Bachelor of Science in Nursing in the year 2000 and then devoted myself to my growing family and my nursing career. In the back of my mind, though, this dream quietly lived and flourished.

In 2018 , when my youngest son turned 18 , I decided it was time to try and 
attain my dream. I was filled with excitement but also with trepidation. I wondered if I could achieve my goal after being out of the academic field for 18 years. Would I be able to succeed at a higher level of learning? Would I be disciplined enough to manage a family, a home, a career, and an education? I wasn't sure, but I knew I wanted to try. I thought of the words of Johann Wolfgang von Goethe, "What is not started today is never finished tomorrow" (Edberg, 2020a).

The Master of Nursing program I enrolled in was online, and the courses were self-paced. When I started my first two courses, I felt lost in all the new technology; the online conferencing, the forums, and I thought that I might fail. As well, some people discouraged me and asked why I was going back to school at my age? I knew that the initial difficulties I faced were due to rusty study habits that could be re-trained and that in time I would familiarize myself with the online format. I reflected on my decision again and finally answered with a quote by George Bernard Shaw, 'You see things; and you say, 'Why?' But I dream things that never were; and I say, 'Why not?"' (Edberg, 2020a).

At the beginning of my academic journey, I found the work demanding, and often time-management was a problem. My first assignment was not as successful as I had expected (not failing but not the A I hoped for), and I questioned my decision again. I thought about withdrawing from the program, but one of my instructors reached out to me and asked me to call her. The professor asked me to explain what thoughts I was trying to express and convey in my assignment. She actively listened to my answers and encouraged me with understanding. That phone call instilled new confidence and motivated me to continue to walk down the path that eventually led to my graduation. I didn't know it at the time, but I had just encountered an exceptional educator who espoused a pedagogy of kindness.

In using a pedagogy of kindness as her teaching philosophy, the instructor in my story motivated me to continue my studies and made me feel valued as both a student and a human being. In allowing me to voice my opinions and thoughts actively she made the newly gained knowledge more meaningful, and as described by Giroux (1997) “emancipatory”. Throughout my academic journey, I noticed that many educators I considered outstanding seemed to exude empathy, understanding, and concern and thereby inspired me academically. My educational experiences were all positive and enriching during my two years of study, yet some experiences were more inspiring than others. The factors that elevated class participation and engagement to a higher level were due to the qualities I observed in these exceptional educators. Looking back now, I realize the instructors who made the most significant impact on my life and learning (and on the lives and learning of other students) were those educators who used a pedagogy of kindness as their teaching philosophy. In brief, they cared.

In another instance, when I reflect on my most influential, enriching, and memorable course on the topic of leadership, I realize that the instructor (who 
was an inspiration to us all) formed a mutually respectful and trusting educator-learner relationship with each student in our class. Our professor had all the attributes of an outstanding educator, and she consistently conveyed a teaching philosophy founded on a pedagogy of kindness. She was able to identify with each student and was able to meet each learner's unique needs in a compassionate and individualized approach.

Denial (2019) and Serbati et al. (2020) describe exceptional educators as those who have a passion for teaching, empathy toward students, and who feel that students' contributions to the development of teaching strategies are valuable and beneficial. Exemplary teachers are also knowledgeable about their subject matter and use innovative and creative teaching methods to engage students and capture their attention (Hativa et al., 2001; Khan \& Armstrong, 2019). Outstanding educators can identify with students and understand and better meet their individual and diverse needs (Loreman, 2011). Inspiring teachers help build an "intellectual community" and foster a learning environment of open communication and collaboration to help stimulate thoughts on social justice (Magnet et al., 2014). As well, exceptional teachers can adapt to existing challenges in higher education, such as technological advancements in teaching methods, movement from a traditional to online learning milieu, and increasingly diverse student populations (Contact North, 2015; Henard \& Roseveare, 2012).

Our instructor in the leadership class mentioned above exemplified the qualities of an extraordinary educator who abided by a pedagogy of kindness. At that time, not being aware of kindness as a strategy in pedagogy, I could not articulate these thoughts. Now, on reflection, I understand why the instructor and the course were so exceptional. Our learning activities were inspiring, innovative, and thought-provoking. The class debates and dialogues were always stimulating and engaging. Every student participated with enthusiasm. We were encouraged and gently guided by our instructor to voice our opinions, thoughts, and feelings and reflect on personal experiences and apply them to our discussions. As learners, we sometimes had different viewpoints as we came from diverse backgrounds and had different life experiences. Yet, our teacher made each one of us feel that our opinions were valid and important. Through these discussions, we built connections and learned to collaborate with others.

Other instructional activities stirred our emotions and helped us achieve affective domain learning outcomes. We explored photos, videos, and inspirational quotes related to the course themes in terms of what they meant to us and our work and personal experiences. We were encouraged to explore our feelings, attitudes, biases, and values. Every sense was stimulated and engaged through these activities, and that made the class a satisfying and enriching experience. As the literature revealed, and demonstrated in this class, strong educator-learner relationships and challenging learning environments lead to increased student engagement, increased insights into social injustices, and improved learner outcomes. The students in this class strived harder and accomplished more due to 
the teacher's encouragement and validation that our thoughts were important and valuable. The sharing of thoughts and ideas, many different from our own, enabled us to understand our differences and to raise our awareness of social injustice. The instructor's pedagogy of kindness was the foundation of her, and our, success.

\section{An Educator's Reflection on a Pedagogy of Kindness}

As children we are all taught to be kind. It is the Golden Rule, "Do unto others as you would have them do unto you" (Puka, 2020, para. 1). Kindness has roots in religion, sociology, philosophy, and psychology but does it have a place in education? Values associated with the Golden Rule such as empathy and caring are considered attributes of "good" people but are they appropriate and useful values of exemplary educators?

Kindness is defined as "the quality of being generous, helpful, and caring about other people, or an act showing this quality" (Cambridge University Press, n.d.). When we become educators, we are counselled that we must be fair, well-prepared, credible, and scholarly but being kind or empathic toward learners is seldom mentioned. Specifically, I was encouraged to maintain professional distance from students and to be serious and even strict especially during the initial classes in a semester. The rational for presenting with this demeanor was to "keep students from taking advantage of me" and to ensure that I maintained discipline and order in the classroom.

As I proceeded through my almost 30-year career teaching in-person, blended, and online classes in higher education institutions I began to question this advice. I read about the "pedagogy of kindness" and the "pedagogy of care" and I realized what an essential role the educator's values play in the student experience. Willard (1929) was an early believer in the role of kindness in successful teaching and learning and Arnold (2005) specified the value of empathy in the form of empathetic intelligence as part of a pedagogy of kindness.

In discussing the evolution of a pedagogy of kindness in higher education Magnet et al. (2014) note that kindness has traditionally been feminized and devalued. These same authors assert that being kind, as a pedagogical strategy, can eliminate dominance, oppression, and competition in the academy (Magnet et al., 2014) facilitating justice and a sense of community (Palahicky, et al., 2019). Loreman (2011) frames this approach to teaching as love which includes kindness, empathy, intimacy, and bonding, sacrifice and forgiveness, and acceptance and community.

Through various experiences with students (and considerable self-reflection), I learned that an educator's values impact student performance and therefore specific values, such as those that are part of a pedagogy of kindness, are essential to teaching success (Palahicky, et al., 2019). An early formative experience with a nursing student I will call Jasmine started me on the path of integrating kindness into my practice. Jasmine was a quiet learner, always attending class 
but rarely speaking up to answer or ask questions. She always seemed somewhat preoccupied and left the classroom the instant class was over without socializing with the other students. I found myself concerned about her state of well-being and as the term progressed her physical appearance became increasingly disheveled and the preoccupation and vacant glances out the window during class happened more often. As my concern for Jasmine grew, I felt a need to reach out to her to see if she needed help, yet I held back as my colleagues all warned again "getting involved" in a student's personal life. Yet her personal situation seemed to be negatively impacting her academic performance, so I decided to act.

The next day in class Jasmine appeared agitated and even more aloof and I couldn't resist any longer. I slipped her a tiny yellow sticky note that said, "if you need to talk, I am here for you." Although I waited Jasmine didn't come to me after class to pour out her heart as I had anticipated. She continued to come to class, finished the term, and passed the course. On the last day of our class she dropped an envelope on my desk. I opened it after everyone had departed. Inside the envelope was my little yellow sticky note and under my words "if you need to talk, I am here for you" Jasmine had written "thanks for caring, it made all the difference." I still have that sticky note in my box of special teaching memories.

Jasmine taught me much about how a pedagogy of kindness can lift a struggling learner so that that person can keep pursuing their academic goals. She also taught me that acts of kindness and empathy do not necessarily have to be overly time-consuming, intense, or "big" overtures. Kindness is often most intensely experienced through seemingly tiny gestures rendered with sincerity. Finally, the experience with Jasmine taught me that a pedagogy framed in kindness has positive effects on learners, but it equally has positive impacts on educators. A pedagogy of kindness has mutual benefits. I may have helped Jasmine with my small act of kindness and a willingness to be open to her sharing her worries and circumstances with me, but she equally impacted me in a positive way. As an educator knowing that I can care about students and rather than losing control of the discipline of the classroom I can enhance their learning experience and support them to succeed gives me intense career fulfillment. It also motivates me to continue to strive to be the best educator I can be.

\section{Conclusion}

Inspirational educators who adopt the use of kindness (including care and compassion) in their pedagogy engage and motivate students to try harder in their academic efforts leading to positive student outcomes (Hativa et al., 2001; Serbati et al., 2020). The literature consistently shows that extraordinary instructors who espouse a teaching philosophy founded on a pedagogy of kindness make a significant impact on students' lives and learning achievements (Clegg \& Rowland, 2010; Groves et al., 2015; Hativa et al., 2001; Serbati et al., 2020; Thomas, 2019). These exceptional teachers understand the unique needs of students from diverse backgrounds and cultivate learning environments that promote a sense 
of community and partnership (Clegg \& Rowland, 2010; Magnet et al., 2014). Through the reflections of a student and an educator on the use of kindness in pedagogy, we realize that learners who encounter educators abiding by this teaching philosophy are fortunate. Not only do these students potentially have better learning outcomes, but their academic experiences are also enhanced, and their personal lives may be made richer. Extraordinary educators who make learners feel valued increase the possibility of academic success while reinforcing students' worth as human beings. Inspirational educators also encourage sharing diverse thoughts, opinions, life experiences, and values and thereby advance reflection on social justice (Clegg \& Rowland, 2010; Magnet et al., 2014). Kindness is a quality in instructors that is not always encouraged by institutional administrators and may be criticized as too emotional and not rigorous enough for academia (Clegg \& Rowland, 2010). Yet, as demonstrated in the reflections, this teaching approach can have profoundly positive effects on learners and educators. We argue that kindness can and should play a valuable role in pedagogy in higher education because it can positively influence learner environments, learning outcomes, teaching success, and promote discourse on social justice. Encouraging a pedagogy of kindness is much more that being kind, it is a pedagogy that challenges learners to see beyond their existing world views to appreciate and value self and others. It helps build resilience and confidence in students making them better citizens and more compassionate human beings. Finally, enacting a pedagogy based on values of caring helps educators inspire and be inspired in return.

\section{Founding}

This project was funded by an SSHRC Insight grant.

\section{Conflicts of Interest}

The authors declare no conflicts of interest regarding the publication of this paper.

\section{References}

Arnold, R. (2005). Empathic Intelligence: Teaching, Learning, Relating. Randwick: UNSW Press.

Breuing, M. (2011). Problematizing Critical Pedagogy. International Journal of Critical Pedagogy, 3, 1-23.

https://www.marybreunig.com/assets/files/Problematizing\%20Critical\%20Pedagogy.pdf

Cambridge University Press (n.d.). Kindness. In Cambridge Dictionary. Cambridge: Cambridge University Press. https://dictionary.cambridge.org/dictionary/english/kindness

Clegg, S., \& Rowland, S. (2010). Kindness in Pedagogical Practice and Academic Life. British Journal of Sociology of Education, 31, 719-735.

http://www.jstor.org/stable/25758494

https://doi.org/10.1080/01425692.2010.515102

Contact North (2015). The Future of Higher Education: A Canadian View.

https://teachonline.ca/sites/default/files/pdfs/perspective on the future of higher ed 
ucation.pdf

Denial, C. (2019). A Pedagogy of Kindness. https://hybridpedagogy.org/pedagogy-of-kindness

Edberg, H. (2020a). 55 Inspiring Quotes on Dreams (and on Making Them Real). The Positivityblog. https://www.positivityblog.com/quotes-on-dreams

Edberg, H. (2020b). 80 Inspirational Education Quotes for Students and Teachers. The Positivityblog. https://www.positivityblog.com/quotes-on-education

Giroux, H. (1997). Pedagogy and the Politics of Hope. Boulder, CO: Westview Press.

Groves, M., Sellars, C., Smith, J., \& Barber, A. (2015). Factors Affecting Student Engagement: A Case Study Examining Two Cohorts of Students Attending a Post-1992 University in the United Kingdom. International Journal of Higher Education, 4, 27-37. https://doi.org/10.5430/ijhe.v4n2p27

Hativa, N., Barak, R., \& Simhi, E. (2001). Exemplary University Teachers: Knowledge and Beliefs Regarding Effective Teaching Dimensions and Strategies. The Journal of Higher Education, 72, 699-729. http://www.jstor.org/stable/2672900 https://doi.org/10.1080/00221546.2001.11777122

Henard, F., \& Roseveare, D. (2012). Fostering Quality Teaching in Higher Education: Policies and Practices. Paris: OECD.

https://www.oecd.org/education/imhe/QT\%20policies\%20and\%20practices.pdf

Hooks, B. (2003). Teaching Community: A Pedagogy of Hope. New York: Routledge.

Khan, S., \& Armstrong, A. (2019). Math-a-Polka: Mathematics as a Place of Loving Kindness. Journal of the Canadian Association for Curriculum Studies, 17, 1-12. https://jcacs.journals.yorku.ca/index.php/jcacs/article/viewFile/40441/36419

Loreman, T. (2011). Kindness and Empathy in Pedagogy. In T. Loreman (Ed.), Love as Pedagogy (pp. 15-31). Rotterdam: Sense Publishers. https://doi.org/10.1007/978-94-6091-484-3

Magnet, S., Mason, C., \& Trevenen, K. (2014). Feminism, Pedagogy, and the Politics of Kindness. Feminist Teacher, 25, 1-22. https://doi.org/10.5406/femteacher.25.1.0001 http://www.jstor.org/stable/10.5406/femteacher.25.1.0001

Palahicky, S., DesBiens, D., Jeffery, K., \& Stuart Webster, K. (2019). Pedagogical Values in Online and Blended Learning Environment in Higher Education. In J. Keengwe (Ed.), Handbook of Research on Blended Learning Pedagogies and Professional Development in Higher Education (pp. 79-101). Hershey, PA: IGI Global.

https://doi.org/10.4018/978-1-5225-5557-5.ch005

Puka, B. (2020). Golden Rule. The Internet Encyclopedia of Philosophy. https://iep.utm.edu/goldrule

Serbati, A., Aquario, D., Da Re, L., Paccagnella, O., \& Felisatti, E. (2020). Exploring Good Teaching Practices and Needs for Improvement: Implications for Staff Development. Journal of Educational, Cultural and Psychological Studies (ECPS Journal), No. 21, 43-64. https://doi.org/10.7358/ecps-2020-021-serb

Siegel, H. (2010). Introduction: Philosophy of Education and Philosophy. In The Oxford Handbook of Philosophy of Education (pp. 1-7). Oxford: Oxford University Press. https://www.oxfordhandbooks.com/view/10.1093/oxfordhb/9780195312881.001.0001/o xfordhb-9780195312881-e-001?print=pdf

Thomas, W. (2019). Pedagogy of Care. https://willt486.github.io/teaching/2019/08/23/pedagogy-of-care

Weiler, K. (2001). Feminist Engagements. Reading, Resisting, and Revisioning Male Theor- 
ists in Education and Cultural Studies. New York: Routledge. https://doi.org/10.4324/9780203902653

Willard, E. B. (1929). Kindness as a Factor in Pedagogy. Journal of Education, 110, 151-153. https://doi.org/10.1177/002205742911000704 